\title{
THE SURPRISING FRENCH EMPLOYMENT PERFORMANCE: WHAT LESSONS?
}

\author{
JEAN PISANI-FERRY
}

CESIFO WORKING PAPER NO. 1078

CATEGORY 4: LABOUR MARKETS

NOVEMBER 2003

Presented at CESifo Conference on Unemployment in Europe, DECEMBER 2002

An electronic version of the paper may be downloaded

- from the SSRN website:

- from the CESifo website:

www.SSRN.com

www.CESifo.de 


\title{
THE SURPRISING FRENCH EMPLOYMENT PERFORMANCE: WHAT LESSONS?
}

\begin{abstract}
Although widely regarded as a textbook case of a rigid economy, in the late 1990s France was able to increase employment by 10 per cent within five years and to cut down unemployment by more than a fourth. This paper investigates what factors may account for this surprising performance. The evidence suggests a significant shift in the demand for labour, that can be partially ascribed to cuts in social security contributions introduced in the 1990s and to the later move to a 35 hours work week. Although a large proportion of companies reported difficulties in hiring, the sharp reduction in unemployment did not result in significant wage pressure. Nevertheless, new measures aiming at fostering labour supply were introduced in the early 2000s. The emphasis on stimulating labour demand that characterised French labour market policies in the 1990s was more successful than expected by observers. This lends support to the advocates of active labour market policies. However, the budgetary cost of this approach has also been high. Whether this strategy is sustainable in the medium run is likely to become increasingly an issue.
\end{abstract}

JEL Classification: J48, J68.

\author{
Jean Pisani-Ferry \\ University Paris-Dauphine \\ 62 Boulevard Richard Lenoir \\ F75011 Paris \\ France \\ jean@pisani-ferry.net
}

This is a revised version of a paper prepared for the CESifo-Yrjö Jahnsson Foundation Conference on Unemployment in Europe held in Munich on 6-7 December 2002. I wish to thank the Direction de la prévision as well as Frédéric Lerais and the DARES for both data and discussions. I am grateful to Gilbert Cette, Juan Jimeno and Bertrand Martinot for stimulating comments. 


\section{Introduction}

From the mid-1970s until the late 1990s, France looked as the textbook case of a rigid European economy, where employment was essentially flat and ever-rising unemployment could only experience temporary breaks. International organisations routinely estimated the NAIRU to be perilously close from actual unemployment and most outside observers confidently asserted that anything short of a radical labour market overhaul would fail to remedy this dismal situation.

Yet within five years, France has been able to increase employment by $10 \%$ and to cut down unemployment by more than a fourth. In some respects, the French economy of the early 2000s resembles more the slow productivity-high job creation the US economy of the 1980s than the standard fast productivity-low job creation European economy of the same period.

France's recent performance is not unique. Aggregate employment growth has significantly improved in the EU over the last cycle and some member states, such as Spain, have experienced record job creation. Yet France is very specific in some respects: its labour market institutions are frequently ad odds with existing European models and the policies it has adopted - especially but not only the working time reduction - have generally not been implemented elsewhere.

This paper examines the French employment and unemployment record with particular emphasis on the recent performance. Part 2 provides an overview of what has happened and puts recent years in historical perspective. Part 3 is devoted to discussing what can account for the observed changes in employment and unemployment trends. Part 4 focuses on current policy issues. Part 5 offers conclusions.

\section{Facts}

Between 1900 and 1960, the French economy barely created a single job. According Marchand and Thélot (1997), total employment fluctuated around 19 million. Obviously, job destruction was taking place in agriculture while new jobs were created in industry and services, but the aggregate figure remained remarkably flat.

As the labour force started to expand again, the 1960s saw a noticeable increase in employment (Figure 1). Two million jobs were created until 1974 in a high growth, low unemployment context. But from the mid-1970s to the late 1990s, the picture changed dramatically: average annual employment growth did not exceed $0.2 \%$ and only 1 million new jobs were created between 1973 and 1996. Unemployment, which was virtually non- 
existent in France as in most other European economies until the early 1970s, rose throughout that period, with only one significant interruption in the late 1980s (Figure 2). From the 1970s on, each of the major macroeconomic shocks - the oil prices hikes, the rise in real interest rates, disinflation, German unification and the ERM crisis - was associated with an increase in unemployment. In the mid-1990s, the perception that any temporary increase in unemployment would tend to become persistent was widespread among economists and policymakers. France was a perfect example of the Blanchard-Wolfers (2000) view that unemployment could be ascribed to the perverse interaction of shocks and institutions.
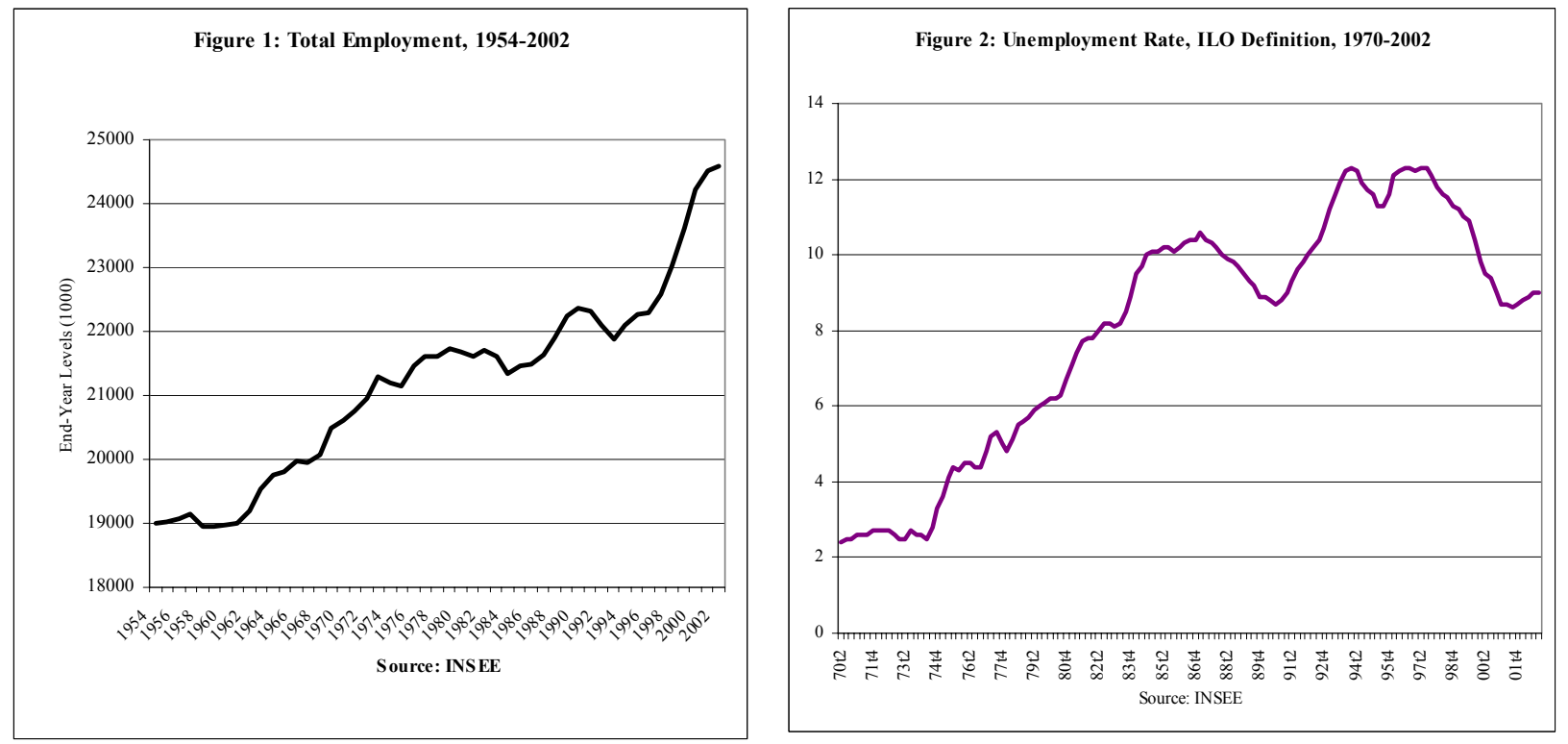

The employment expansion of the late 1990s-early 2000s was thus remarkable. Within five years, from end-1996 to end-2001, 2 million jobs were created and unemployment (ILO definition) was reduced from $12,1 \%$ to $8,6 \%$ of the labour force before picking up as a consequence of the economic slowdown which started in 2001. This evolution came as a surprise to virtually all observers ${ }^{1}$.

The reduction in unemployment affected all categories, but it was especially pronounced for youth unemployment, as apparent in Table 1 which provides unemployment rates by age and sex for January 1997 (when unemployment reached a maximum), May 2001 (the recent minimum) and end-2002.

\footnotetext{
${ }^{1}$ In 1997, a medium term projection released by the ministry of Finance (1997) envisaged 3\% annual growth in 1998-2002 but in spite of this optimistic assumption reckoned that the unemployment rate would still stand at $11 \%$ at end-2002. In a report to the Prime minister, Olivier Blanchard and Jean-Paul Fitoussi (1998) reached somewhat less pessimistic but qualitatively similar conclusions.
} 
Table 1: Unemployment Rates by Age and Sex, 1997-2002

\begin{tabular}{|l|r|r|r|r|r|r|r|r|r|r|r|r|}
\hline & \multicolumn{9}{|c|}{ Men } & \multicolumn{4}{|c|}{ Women } & \multicolumn{3}{|c|}{ All } \\
\hline & $\mathbf{1 5 - 2 4}$ & $\mathbf{2 5 - 4 9}$ & $\mathbf{7 4 9}$ & \multicolumn{1}{|c|}{ all } & $\mathbf{1 5 - 2 4}$ & $\mathbf{2 5 - 4 9}$ & $\mathbf{7 4 9}$ & all & $\mathbf{1 5 - 2 4}$ & $\mathbf{2 5 - 4 9}$ & $\mathbf{> 4 9}$ & all \\
\hline Jan 1997 & 25.1 & 9.8 & 7.9 & 10.7 & 34.8 & 13.2 & 8.5 & 14 & 29.4 & 11.3 & 8.2 & 12.2 \\
\hline May 2001 & 17.1 & 6.5 & 5.1 & 7.1 & 23.1 & 10.1 & 6.6 & 10.4 & 19.7 & 8.1 & 5.8 & 8.6 \\
\hline Dec 2002 & 19.7 & 7.5 & 5.9 & 8.2 & 24.3 & 9.4 & 6.6 & 10.1 & 21.7 & 8.4 & 6.2 & 9.1 \\
\hline \multicolumn{10}{|c|}{} \\
\hline $1997-2001$ & -8.0 & -3.3 & -2.8 & -3.6 & -11.7 & -3.1 & -1.9 & -3.6 & -9.7 & -3.2 & -2.4 & -3.6 \\
\hline $2001-2002$ & 2.6 & 1.0 & 0.8 & 1.1 & 1.2 & -0.7 & 0.0 & -0.3 & 2.0 & 0.3 & 0.4 & 0.5 \\
\hline
\end{tabular}

The reduction in unemployment was also rather evenly distributed between employees of different education levels. In fact, it was more pronounced in the low-skill segment of the labour force, although its level remained extremely high for that category, especially for women (Table 2). Unemployment decline was less significant in the skilled segment in comparison to 1990, a period in which this category of labour was close to full employment. Two reasons for those evolutions are (i) a significant change in the skill composition of the labour force, as more than two-thirds of the recent entrants have completed secondary education and, (ii) a shift in the demand for low-skill labour, which is discussed in detail below.

Unemployment data give a somewhat distorted picture as participation rates at the two ends of the age distribution are among the lowest in the OECD. A look at employment/population ratios leads to a more sober view: between 1996 and 2001, employment rates rose by about 3 percentage points for the three age groups, but non-employment remained massive. While the low participation rate of younger persons may reflect the rise in educational enrolment and a preference for studying full time (possibly also statistical problems), the same cannot be said for senior workers, whose participation is low and declining.

Table 2: Unemployment Rates by Education Level, 1990-2002

\begin{tabular}{|l|r|r|r|}
\hline & 1990 & 1997 & 2002 \\
\hline Total & 9.2 & 12.3 & 8.9 \\
\hline Primary & 13.0 & 17.5 & 14.1 \\
\hline Short secondary & 8.4 & 11.4 & 8.3 \\
\hline Long secondary education & 6.5 & 11.4 & 8.2 \\
\hline 2 years of University & 3.7 & 8.2 & 5.6 \\
\hline University degree & 3.5 & 7.3 & 5.7 \\
\hline \multicolumn{2}{|r|}{ Source: INSEE, annual employment survey. } \\
\hline
\end{tabular}

Data are for the month in which the survey is conducted (usually March, but January in 1990) 
COR (2002) indicates that only $45 \%$ of men and $42 \%$ of women are in employment at the time of retirement. The majority are either enrolled on an early retirement scheme $(32 \%$ of men and $21 \%$ of women), unemployed (but as they are generally not requested to look for a job, and have a very low probability to being hired anyway, this is practically equivalent to being on early retirement) or inactive. As a consequence, although the average retirement age was just below 60 years for the private sector employees of the 1932-36 cohort, the average age at which they effectively stopped being employed stood at 57.5 (COR, 2002). This gap was virtually inexistent for the older cohorts and did not exceed 1 year for the 1912-1916 cohort. There is no indication that it has been reduced in recent years. In addition, CERC (2001) points out that participation is only $60 \%$ for persons between 25 and 60 without a secondary education, while it is $75 \%$ on average for all education level. For this category, participation has continued to decline in recent years.

Turning to employed persons, a significant proportion of part-time employees indicate that they would wish to work full time. 'Constrained part-time', as it is known in France, has receded in the context of a tighter labour market, but according to the annual employment survey it still affected a third (32.6\%) of the part-time workers in 2002. It should also be mentioned that some 300000 persons are on government-sponsored contracts in local communities, $60 \%$ of which part-time. The number of those contracts fluctuates contracyclically, which is a clear indication that they do not correspond to permanent needs but are rather used as an employment policy instrument.

How large is hidden unemployment? Table 3 suggests that taking into account part-time workers seeking a full-time job and senior workers on early retirement or not seeking a job would have increased by some $60 \%$ the number of people experiencing underemployment. A report by Pisani-Ferry (2000) used a different approach. It relied on a rough calculation of the number of jobs that would have to be created for the French economy to reach full employment in 2010 (defined as 5\% unemployment rate plus an increase participation resulting in a $68.5 \%$ employment ratio, still below the $70 \%$ objective set at the EU Lisbon summit. The study reckoned that reaching that target would imply creating 420000 jobs per year $(+1.6 \%$ per year on average) instead of 300,000 in a constant participation rate scenario and 160,000 on the basis of the labour force projection in use in 2000 , which envisaged a steady decline in the participation rates. In other words, it was assessed that non-participation contributed in a major way to underemployment. 
Table 3: Indicators of Unemployment and Underemployment, 2000

\begin{tabular}{|l|r|r|}
\hline & Millions & \multicolumn{1}{|c|}{$\begin{array}{c}\text { Percent of the } \\
\text { Labour Force }\end{array}$} \\
\hline Unemployment, ILO definition & 2.63 & 10.0 \\
\hline Part-time workers seeking full-time job & 1.1 & 4.1 \\
\hline Senior workers not seeking a job & 0.35 & 1.3 \\
\hline Senior workers on early retirement schemes & 0.2 & 0.9 \\
\hline
\end{tabular}

\section{Accounting for the surprises}

The unexpected labour market improvement of the late 1990s raises two main questions: first, how can the rise in labour demand be explained? Second, why did inflation remain subdued? These puzzles are the focus of this section.

\section{A shift in labour demand}

France is known for having a large government sector. However, in spite of the emplois jeunes (a scheme introduced in 1997 with the aim of creating jobs for persons under 25 in the non-profit and government sectors, which resulted in some 225000 job creations), the net increase in employment in the non-business sector only accounted for some $15 \%$ of total job creation in 1996-2001 (Table 4). Most new jobs were created in the business sector.

Table 4 : Job Creation in France, 1996-2001 (millions)

\begin{tabular}{|cr|}
\hline Total job creation 1996-2001 & 1.96 \\
Non-farm business sector & 1.80 \\
Agriculture & -0.09 \\
Non-business sector & 0.28 \\
- government and non-profit (excl. special schemes) & 0.37 \\
- government and non-profit (special schemes) & 0.09 \\
- military call-up & -0.19 \\
\hline
\end{tabular}

The next usual suspect is economic growth. As was more generally the case in the Euro zone, but to a more significant extent, French output growth accelerated markedly in the late 1990s. The contrast with the dismal growth performance of the early and mid-1990s was striking. But this performance cannot be deemed exceptional in comparison to the late 1980s. As Figure 3 indicates, the difference between the two periods was that employment growth was significantly higher in the 1990s while output growth was roughly comparable. 


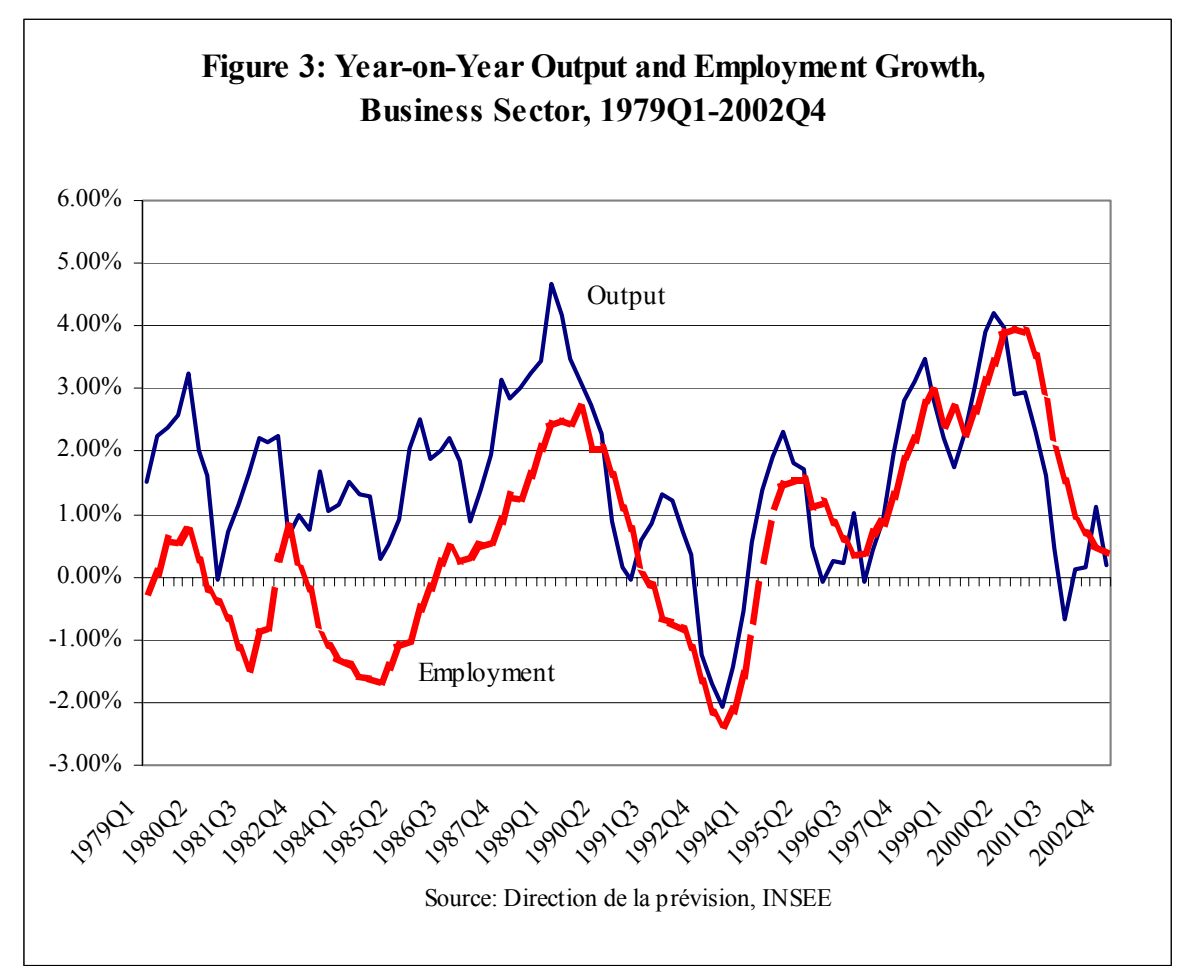

Suspect number 3 is part-time work. Until the early 1990s, part-time work was not widespread in France. At that time, French governments attempted to emulate the Dutch experience. In 1992-93, the hourly cost of a part-time worker at the level of the minimum wage was reduced to $85 \%$ of the cost of a full-time worker through targeted cuts in social security contributions. Part-time work then expanded rapidly in services, from 12\% in 1990 to 16,6\% in 1997 (Gonzalez-Demichel et al., 2002) but those jobs were frequently taken up by persons wishing to work full-time, which gave rise to dissatisfaction. Incentives were progressively cut down and they were eliminated altogether in 1998, as the socialist-led government of Lionel Jospin chose to foster general working time reduction instead. From 1997 to 2002, the share of part-time work actually declined (to 16,2\%). While its development certainly has a role in explaining employment in the mid-1990s, it cannot be regarded as relevant for the late 1990s.

There is thus evidence that the French economy experienced a significant labour demand shift in the late 1990s.

The most direct explanation for the increase in labour demand is that this is precisely what employment policy had attempted to achieve. Until the early 1990s, employment policy had essentially been devoted to containing the rise in unemployment through early retirement and training schemes and as recently as in $1990,80 \%$ of public employment expenditures went to unemployment benefits and early retirement schemes. New priorities emerged in the 1990s 
and while political changes introduced some instability in the definition of targets and instruments, there was in fact a high degree of continuity in the broad direction of policy: most of the effort was devoted to fostering labour demand.

\section{Social security contribution cuts}

A lasting component of this effort has been the introduction of targeted cuts in the employers' social security contributions. They were initiated by the right-wing Balladur government in 1993 after an influential report (Charpin, 1993) had pointed out that although the cost of labour was not especially high in France, it was above average for unskilled workers. The exemption was initially modest, but it was amplified in 1995 and 1996 to reach $18 \%$ of gross wage at the level of the minimum wage, linearly decreasing to zero for 1,33 minimum wage. The Jospin government introduced additional cuts, which were phased-in progressively as companies moved to the 35 hours week. The short-term aim was to use them as a carrot, but the government also regarded those cuts as a structural measure justified in its own right. Finally, one of the first measures of the government appointed by president Jacques Chirac after the right's return to office in 2002 was to amplify the cuts again while making them fully unconditional. This was partly done in order to offset the impact of the planned rise of the minimum wage as the complex multi-minimum system resulting from asynchronous working time reduction is being eliminated ${ }^{2}$, but partly also because the government regards the reduction in non-wage costs as a key element of its employment policy. As a result, cuts in employers' social security contributions at the level of the minimum wage should reach $26 \%$ of the gross wage in 2006 , linearly decreasing to zero for 1,7 minimum wage.

As a result, the relative level of the unskilled workers' take-home pay has been disconnected from the relative cost of unskilled labour (Figure 4): although the former has risen from $46 \%$ in 1990 to $49 \%$ in 2002 , the latter has decreased from $46 \%$ to $42 \%$. This very substantial reduction in the tax wedge at the level of the minimum wage entails a significant cost for the budget, which amounted to $€ 14.4$ bn in 2002 (1\% of GDP) and is expected to increase to $€ 19.6 \mathrm{bn}(1.2 \%$ of GDP) in 2005 .

\footnotetext{
${ }^{2}$ In order to ensure that minimum wage workers would not suffer a reduction in their monthly wage as a consequence of the working time reduction, a legal minimum guaranty was introduced at the level of (39/35)x the minimum wage at the time of the move from a 39 to a 35 hours work schedule. As companies were given latitude to choose at what date they would implement the working time reduction, the minimum wage at the time of the move was not identical for the different cohorts. Hence, the coexistence of five, non converging guarantees, whose level all exceed $35 \mathrm{x}$ the minimum wage. They will be replaced by a single (but higher) minimum wage.
} 


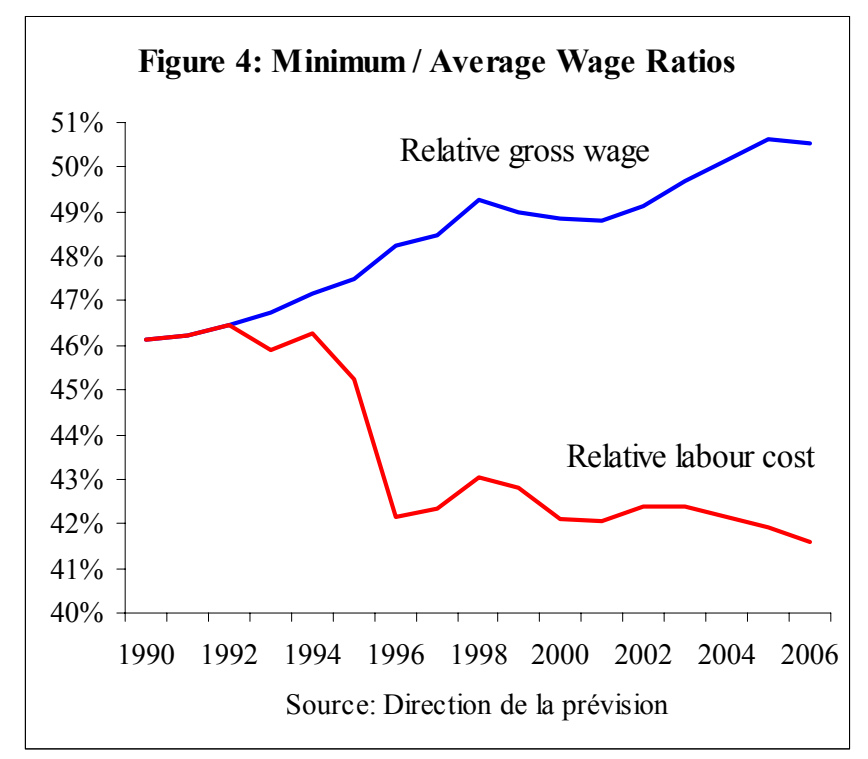

This policy was bound to impact significantly on labour costs, since the French wage distribution is heavily skewed: $14 \%$ of private sector employees are on the minimum wage and $38 \%$ of them (including part-timers) earn less than 1.3 times the full-time minimum wage (INSEE, 2002). This is the natural result from a long-standing policy of using increases in the minimum wage as an income policy instrument. For a large part of the employed population, changes non-wage costs thus directly translate into labour cost reductions.

Most of the existing research on the effects of this policy has relied on ex-ante simulations based on estimated labour demand parameters. Those evaluations, which frequently rely on a three-factors production function where unskilled labour is regarded as substitutable to a capital-skilled labour aggregate, estimate the effect of the cuts in place before the 1998 reform around $250,000-300,000$ jobs, a $2 \%$ increase in private employment (see the surveys in Cahuc, 2002, Campens et al., 2001, and Pisani-Ferry, 2000) ${ }^{3}$. The government services' own evaluations are consistent with this order of magnitude.

Crépon and Desplatz (2001) provide the first and so far only attempt at an ex post evaluation of the impact of the cuts on the basis of micro data. They base their research on a comparison between the employment behaviour of the companies who benefited from the cuts and those who did not (or only benefited to a minor extent). Their point estimate, 460000 jobs already in 1997 (but with a wide confidence interval) has however been disputed because it was regarded as implausibly high (L'Horty, 2001, Sterdyniak, 2002, Crépon and Desplatz 2002).

\footnotetext{
${ }^{3}$ These are partial equilibrium simulations, which do not take into account the impact of financing the contribution costs. It is often claimed that this policy is self-financing, because it essentially activates passive labour market policies, however, the revenues accrue to the social security (which is managed by social partners) while the costs are supported by the state budget.
} 
Evidence from employment surveys suggests that the reduction in the cost of labour at the level of the minimum wage effectively halted the decline in the proportion of unskilled jobs after the social security contribution cuts were introduced in 1993-94. However, in the stagnant context of the mid-1990s, unskilled workers were frequently crowded out by more educated ones who had been unable to find a job corresponding to their skills (Audric, 2001). This phenomenon only began to recede after unemployment had declined for several years. Recent research suggests it is still present (Nauze-Fichet and Tomasini, 2002)

Summing up, available evidence suggests that the cuts in social security contributions have contributed to increasing employment. The obvious downside has been that measured labour productivity has slowed down as more low-productivity workers were included in employment. While in the 1980 s and early 1990s high productivity gains (especially in comparison to the US, where economists were puzzled by the decline in labour productivity and the public alarmed by the spread of McJobs) resulted from the exclusion of those workers from employment, from the mid-1990s on the opposite evolution took place (unsurprisingly, the French began lamenting about McJobs, while economists started to be puzzled by low productivity gains). Labour input in France is still measured without correcting for changes in quality, but a back-of-the envelope calculation suggests this effect could be significant: assuming the share of unskilled labour in total employment was stabilised instead of declining by $0.4-0.5$ percentage points per year, and that the productivity of an unskilled job is half that of an average job, the evolution that has been observed since the mid-1990s could account for a quarter of a percentage point decline in measured labour productivity growth ${ }^{4}$.

\section{The 35 hours experiment}

Although inspiration was different, the working time reduction implemented by the Jospin government also aimed at boosting labour demand. There were three main rationales for $\mathrm{it}^{5}$.

The first one was simply work sharing, for which support was strong (although economists had warned against the fallacy that the available amount of labour could be considered as given, their arguments carried little weight in the stagnant employment of context of the mid1990s). A more sophisticated version of the argument started from the observation that the historical trend towards reducing working time had come to a halt in the 1980s. Provided the legislated reduction in working time only anticipated the natural trend, it could reduce

\footnotetext{
${ }^{4}$ Recent research by Melka et al. (2003) finds that the growth rate in the quality of employed labour has declined by this amount between the first and the second half of the 1990s.

${ }^{5}$ The rationale for a working time reduction is presented in Cette and Taddei (2000) and Taddei (1997)
} 
unemployment and limit hysteresis in the medium run without affecting the long run choice between income and leisure.

The second rationale was to use the 35 hours week as a banner to signal an overriding priority for job creation. A recurrent policy theme of the 1990s was that in France, as in several other European countries, priority had consistently be given to individual wage gains at the cost of stagnating employment. For the left, working time reduction could be regarded as an acceptable quid pro quo for wage moderation ${ }^{6}$. In a way, the 35 hours were a metaphor for a wider employment-oriented social compromise.

The third rationale was a more indirect one. France's industrial relation system combines weak and fragmented unions (at least in the private sector) and a relatively rigid and above all complex system of labour laws, which in large part result from collective agreements negotiated at the industry or the national level and are given the force of law by government decision. Contrary to what is frequently assumed, those agreements have little bearing on wage formation, for which negotiation (if any) is extremely decentralised ${ }^{7}$. As a result, negotiations are infrequent and rarely ambitious: before the working time reduction process was initiated, less that one-fourth of private sector employees were covered by a firm-level collective agreement (Barrat and Daniel, 2002). Against this background, the working time reduction was regarded as an occasion to encourage decentralised negotiations at the company level in which discussions would be held simultaneously on work organisation, wages and employment. The aim was to foster 'efficient' agreements involving productivity-enhancing reorganisation or the adoption of more flexible arrangements; wage moderation; and job creation. The justification was that those efficient agreements were prevented from happening spontaneously for two reasons: first, because of ossified industrial relations and second, because employment creation involved an externality in the form of a reduction of the unemployment insurance contributions burden.

In this spirit, significant changes to labour regulation were made possible by law on the occasion of the move to the $35 \mathrm{~h}$ workweek: for example, working time could be defined in annual terms rather than weekly terms. An incentive element was also added through

\footnotetext{
${ }^{6}$ This is why the process was launched by a conference on employment, wages and working time chaired by the Prime minister, whose aim was to emulate the famous Dutch Wassenaar agreements. The conference however ended in a bitter dispute between the government and the employers federation, and no further negotiations took place at the central level.

Apart from public-sector pay, the only way centralised decisions affect wage formation is through setting the minimum wage, which increases annually according to a formula combining $100 \%$ ex post price indexation and $50 \%$ indexation on average hourly real wage gains, plus a discretionary increase decided by the government.
} 
conditional cuts in social security contributions, which were meant to internalise the job creation externality.

Working time reduction actually started in 1996 with the Robien law introduced under the right-wing government of Alain Juppé. At that time, the approach was based on social contribution incentives and did not involve changes in the legal working time. After a new majority had come to power with the aim of moving to a $35 \mathrm{~h}$ workweek, it was phased in two steps: in 1998, additional incentives were introduced for companies moving to $35 \mathrm{~h}$. In 2002 , the legal working time was lowered from $39 \mathrm{~h}$ to $35 \mathrm{~h}$ per week, but additional overtime leeway was temporarily introduced and small business was given supplementary delays. After the presidential and general elections of 2002, the new government decided not to change the legal working time, but the overtime leeway was extended and all social security contribution cuts were be made unconditional. Both sticks and carrots have thus been eliminated and companies have no incentive to working time reduction anymore ${ }^{8}$. It is thus unlikely that it will be significant in the years ahead.

At mid-2002, about $60 \%$ of employees in the business sectors had moved to a new working time schedule (ministry of Finance, 2002). The proportion was $80 \%$ in companies with 20 employees or more, but only $20 \%$ in companies with less than 20 employees. As a consequence, average working time in the business sector has been reduced by $4.5 \%$ between 1998 and 2002.

The actual experience was very far from a mere work sharing. Total hours worked expanded significantly at the time the workweek was reduced (Figure 5). But the impact of the 35 hours on employment is still controversial. Most estimates of its effects, even careful ones (see, e.g., Heyer and Timbeau, 2000) are based on a similar methodology and suffer from the same shortcomings. They inject back-of-the envelope calculations of the ex ante effects of work sharing - based on esstimates of the proportion of companies effectively implementing working time reduction and the efficiency gains brought by reorganisation - into a macroeconometric model. The ex post effects thus differ to the extent that (i) working time reduction entails an increase in unit labour costs and (ii) the decrease in unemployment gives rise to wage and price increases. Depending on assumptions and parameters, the expected employment gains range between 200,000 and 500,000. These are obviously short and medium term effects. In the long run, working time reduction cannot have positive effects on

\footnotetext{
${ }^{8}$ For those remaining on a 39 hour schedule, the only practical consequence is a $10 \%$ surcharge on hours worked beyond the $35^{\text {th }}$.
} 
unemployment in such a setting, as the unemployment rate converges towards the NAIRU, unless there is significant hysteresis (Cette, 2000) ${ }^{9}$.

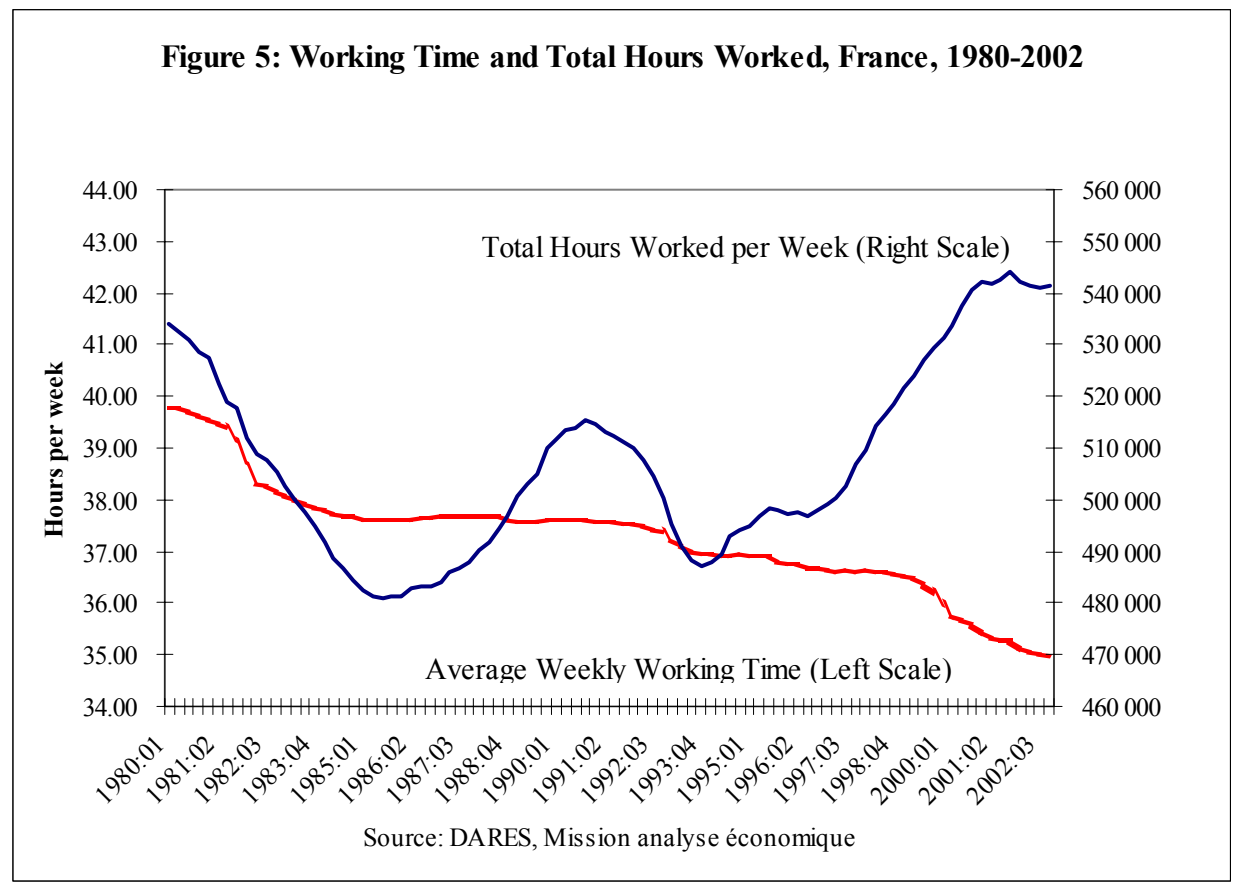

No comprehensive ex post evaluation of the impact of the $35 \mathrm{~h}$ initiative has been published so far, but partial indications are available based on the comparative behaviour of the companies that embarked early on working time reduction (Rouilleault, 2001). They suggest that those companies have effectively achieved significant productivity gains and increased employment. After correcting for selection bias, corresponding estimates of the overall effect of the working time reduction are of the order of magnitude of 300,000 jobs (Jugnot, 2002). But they are surrounded by significant uncertainty.

Table 5 decomposes the effects of working time reduction on unit labour costs as estimated by the ministry of Finance. It suggests that thanks to a combination of wage moderation, productivity gains and social security contribution cuts, the 35 hours have not given rise to an increase in unit labour cots. Assuming it has had no effect on output (which is consistent with the result that unit labour costs have remained roughly constant), it suggests employment could have risen by $2.1 \%$ in $1998-2002$ (the opposite of the decline in productivity per head), which also corresponds to 300,000 jobs.

\footnotetext{
${ }^{9}$ Working time reduction has also been studied in a long run setting (d'Autume et Cahuc, 1997, Cahuc, 2001) where labour demand is determined by an explicit profit-maximisation behaviour and wages result from a bargaining process. Results depend on the choice of parameters. Long run positive effects on employment are possible if significant productivity gains are realised on the occasion of the working time reduction and if it is supported by public subsidies, but negative effects can easily be found.
} 
This evaluation is fragile. First, it is not based on an explicit methodology for correcting selection bias. Second, the measured effects are short- and medium-term ones and the longterm effects should be less favourable, after the full effects of working time reduction on the cost of labour and labour market equilibrium conditions are taken into account. This especially applies to the minimum wage, which is going to increase by more than $10 \%$ in real terms as a consequence of the elimination of the multi-minimum system. Finally, as for (unconditional) social security contributions cuts, the approach remains a partial equilibrium one. Nevertheless, it suggests that working time reduction has played a significant role in the recent employment record of the French economy.

Table 5: Effects of Working Time Reduction, 1998-2002

\begin{tabular}{|l|r|}
\hline Impact of the working time reduction on average: & \\
\hline Working time $(1)=(2)-(3)$ & $-4.5 \%$ \\
\hline - Labour productivity per head (2) & $-2.1 \%$ \\
\hline - Hourly labour productivity (3) & $+2.4 \%$ \\
\hline Monthly wage (4) & $-1.1 \%$ \\
\hline Unit labour costs before social security contribution cuts $(5)=(1)+(4)$ & $-1.0 \%$ \\
\hline Impact of social security contribution cuts $(6)$ & $-1.3 \%$ \\
\hline & $-0.3 \%$ \\
\hline Impact on unit labour costs $(7)=(5)+(6)$ & \\
\hline
\end{tabular}

\section{How welcome is the productivity slowdown?}

Social security contribution cuts and the working time reduction both contributed to reducing output per head, thereby temporarily increasing the "job content of growth". However, they do not suffice to explain the slowdown in labour productivity gains that was observed in France like in several other European countries.

Two other candidates are (i) labour market deregulation and (ii) wage moderation. As a result of legislations introduced in the 1980s and in spite of some regulatory tightening in the 1990s, non-standard work contracts (fixed-term contracts or contrats à durée déterminée-CDD-and interim) have experienced a significant development (Figure 6). Although their share somewhat diminished when a tighter labour markets improved the bargaining position of employees, they represent some $10 \%$ of total employment - less than in other European countries such as Spain, because CDDs cannot be renewed, but still a noticeable development. They impact on labour productivity through two different channels. First, as severance costs and non-monetary costs of separation are typically lower than for standard contracts, CDDs 
reduce the present value of the cost of hiring an employee. Second, as discussed by Blanchard and Landier (2002), CDDs also have the effect of encouraging high turnover for entry-level jobs, with potentially detrimental consequences on efficiency. The first of these effects is comparable to that of a reduction in the cost of unskilled labour and should not affect total factor productivity (if properly measured), but the second one may lead to lowering TFP.

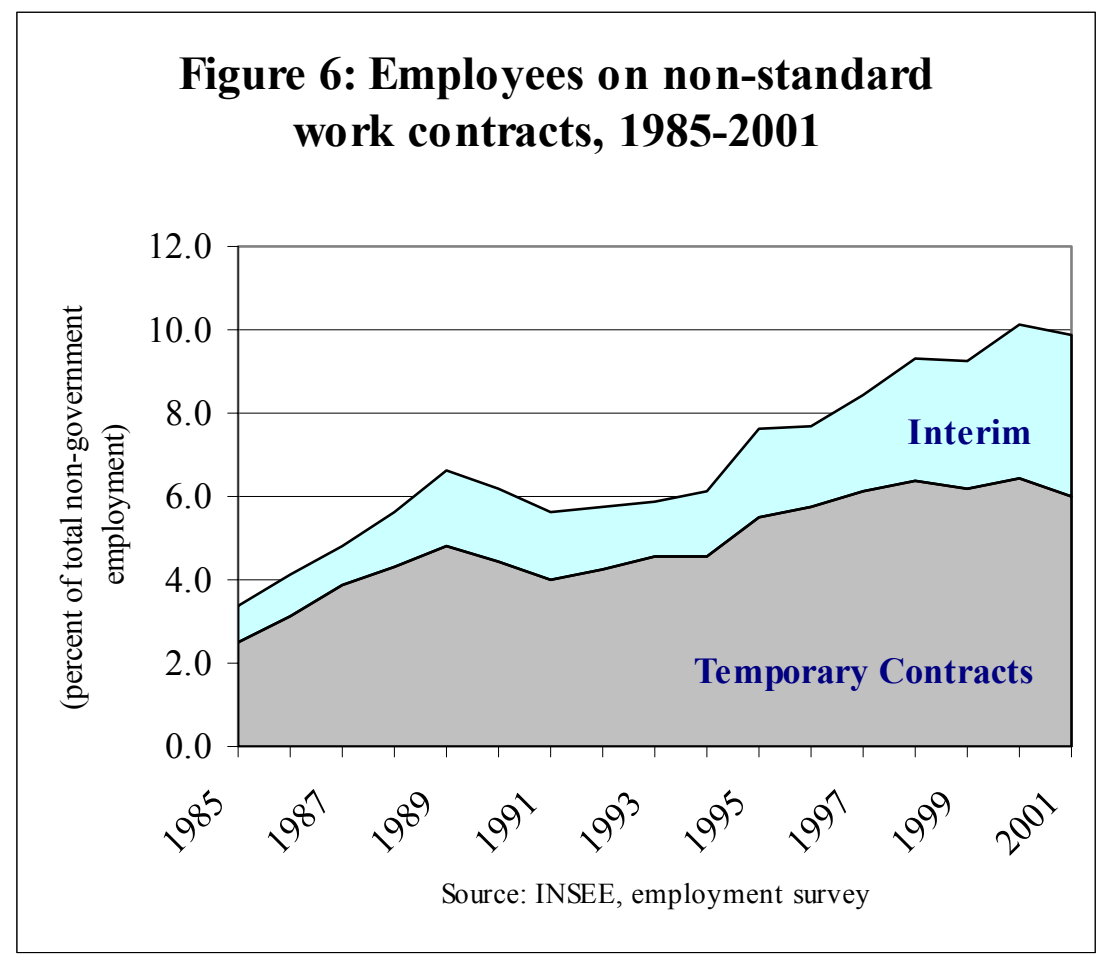

A more general reason for the productivity slowdown is labour deepening as a consequence of protracted wage moderation. Wage moderation has been consistently encouraged by governments since the 1980 s, resulting in a correction of the initial 'wage gap' and a mediumterm drop in the share of labour in value added. This evolution may have resulted in a reversal of the capital deepening which had been observed throughout the 1980s and the early 1990s (Carnot and Quinet, 2000).

Turning to the evidence, Cette, Mairesse and Kocoglu (2002) provide a decomposition of the productivity slowdown, which is reported in Table 6. It suggests that labour deepening may have played an important part in the productivity slowdown but does not find evidence of TFP slowdown. In fact, TFP may have accelerated (which would imply that the transition to a 'jobrich growth' has not been detrimental to efficiency). 
Table 6: A Decomposition of the Labour Productivity Slowdown

(1995-2000 compared to 1990-95, average annual growth rates)

\begin{tabular}{|l|r|}
\hline Labour productivity per head, of which: & -0.5 \\
\hline - Labour deepening & -1.2 \\
\hline - Working time reduction & -0.4 \\
\hline - TFP & +0.6 \\
\hline - Cyclical factors & +0.4 \\
\hline \multicolumn{2}{|c|}{ Source: Cette, Mairesse and Kocoglu (2002) } \\
\cline { 2 - 2 }
\end{tabular}

\section{Why did wage increases remain restrained?}

The second major puzzle of the late 1990s-early 2000s is the persistence of wage moderation in spite of unprecedented employment gains. At the end of the previous phase of expansion, in 1990, wage accelerated markedly as unemployment was approaching 9\%. But this did not happen until 2001, at least for monthly wages, and the acceleration observed in 2001 remained modest by historical standards (Figure 7). Even hourly wage inflation, which was affected by the reduction in working time, remained below the level reached in 1990.

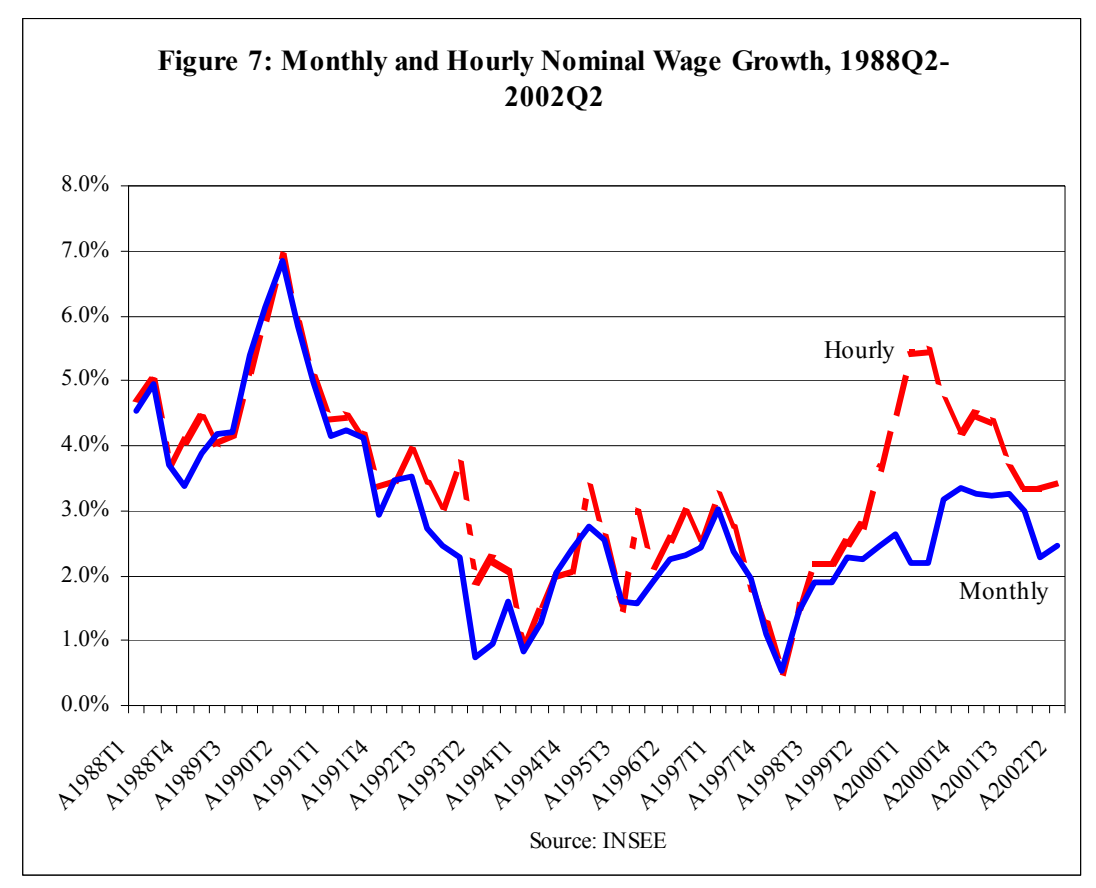

In 1999-2000, most available estimates put the NAIRU between 9 and 11\% (OECD 2000, Pisani-Ferry, 2000), which was consistent with the empirical evidence of the late 1980s. The risk of wage inflation was confirmed by quantity indicators: labour market tensions were visibly on the rise as a growing number of firms reported hiring difficulties, including for low-skill categories. 
Figure 8 provides pseudo-Beveridge curve ${ }^{10}$. Several interesting observations can be made. First, from the mid-1970s to the late 1980s, reported hiring difficulties remained at a low, roughly constant level while unemployment was almost continuously on the rise. When it receded in 1988-90, there was an almost immediate increase in the proportion of firms reporting hiring difficulties, a clear indication that the Beveridge curve had shifted to the right. Together with wage increases, this was strong evidence that structural unemployment was effectively close to $9 \%$. The same kind of behaviour reappeared in the late $1990 \mathrm{~s}$ as the proportion of firms reporting hiring difficulties reached $58 \%$ in 2000 , an all-time record. However, wages did not rise as in 1990.

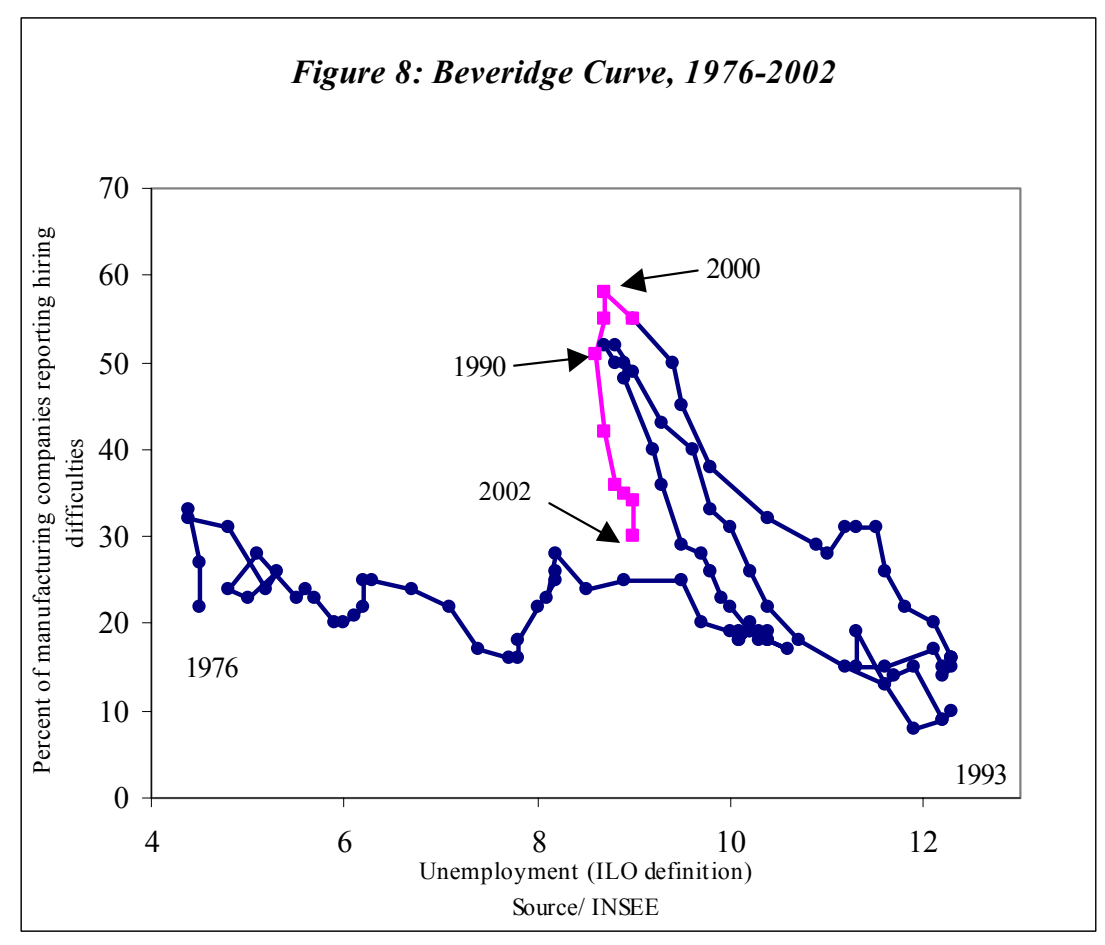

There are basically two potential explanations for this. The most favourable one is that the NAIRU had declined because social security contribution cuts had priced in low-productivity workers who were previously excluded from employment. According to Laroque and Salanié (2000), those cuts should have reduced classical unemployment by two percentage points (which is on the high side of estimates). Other active employment measures targeted at long-

\footnotetext{
${ }^{10}$ As French statistics do not record vacancies in a time-consistent manner, it is not possible to construct a standard Beveridge curve for the French labour market. However, a proxy can be built using surveys on hiring difficulties reported by manufacturing companies. There are two shortcomings in this approach. First, the data only cover a fraction of the labour market which may be subject to specific shortages. Second, survey results can be influenced by the respondent's recent experience: after a period of protracted labour market slack, companies may tend to overestimate the difficulties they are facing in finding suitable candidates to fill vacant positions.
} 
term or youth unemployment may have contributed to the improvement ${ }^{11}$; finally, increased competition within the European market and lower real interest rates should have played in the same direction ${ }^{12}$. This optimistic interpretation can take comfort from the fact that hiring difficulties dropped rapidly in 2001-2002, which suggests that the further shift in the Beveridge curve was more apparent than real: reported hiring difficulties may have reflected problems in adjusting to a high flow of recruitments.

The less optimistic interpretation is that the absence of significant wage inflation should be attributed to a specific factor. As the legal working time reduction took effect on $1^{\text {st }}$ January 2000 for larger companies, most of them had already undertaken or concluded negotiations on its implementation. A large proportion of the agreements (around 73\% for those concluded before 2000 and $47 \%$ for those concluded in 2000) included a 2-3 years wage freeze or a wage moderation clause (Bloch-London, Pham and Zilberman 2002). Wage inflation was thus paradoxically contained by the 35 hours. When the wage moderation clauses expired, the economic context had already deteriorated.

Whatever the interpretation, the coexistence of a high unemployment rate and hiring difficulties could not be taken as an indication that the labour market is working properly. In the early 2000s, realisation that the French economy was moving fast from a demandconstrained to a supply-constrained environment prompted a reorientation of labour market policy priorities.

\section{The emergence of new policy issues}

While the overriding priority of employment and unemployment policy in the 1990s was to encourage the demand for labour, new priorities began to emerge in the 2000s. As employment picked up and unemployment receded, the focus moved to new issues: inactivity traps, their impact on labour supply, and the possible remedies; the reform of the unemployment insurance system; and job security.

\section{Inactivity traps}

France introduced in 1988 a universal minimum income, the Revenu minimum d'insertion (RMI). It was initially supposed to conditional, but in the high-unemployment context of the 1990s, the number of beneficiaries rapidly exceeded all forecasts to reach 1 million at the end

\footnotetext{
${ }^{11}$ As for the US (Katz and Krueger, 1999), demographic changes may also account for a half a percentage point reduction (Pisani-Ferry, 2000).

${ }^{12}$ This is not to say that other factors, such as inactivity traps, have not had a negative role (more on this below).
} 
of the decade. By that time, the incentive component of the RMI had been forgotten and it could be for all practical purposes be regarded as an unconditional income support.

The level of the RMI was initially set at roughly $50 \%$ of the net full-time monthly minimum wage for a single person, with additional income support depending on the structure of the family. This was considered a reasonable compromise between the two objectives of alleviating poverty and encouraging participation in the labour force. But as part-time work developed in the 1990s, a larger number of recipients were confronted with a choice between remaining on the minimum income and taking up a part-time minimum wage job. As the RMI was designed as a differential income, i.e. any labour income up to its level was effectively taxed at $100 \%$, the gain for taking up such a job was nil. What had been conceived as compatible with encouraging participation had in effect become an inactivity trap.

The very strong labour supply reduction triggered by a parental income for non-working mothers with children introduced in 1994 had warned that significant effects could be expected $^{13}$. Significant research was thus devoted to reaching a precise diagnosis. It has revealed that the RMI was in effect only part of the problem, as a number of other benefit such as housing allowances or allowances for single parents had the same characteristics. Laroque and Salanié (1999) have pointed out that 4 million persons were confronted with marginal tax rates on labour income above 90\%. Taking into account the quality of the jobs that persons on the minimum income could be expected to find, Gurgand and Margolis (2001) have shown that the net expected long-term gain from taking up a job was inferior to $€ 100$ per month for one-fourth of the minimum income recipients and between $€ 100$ and $€ 200$ for another fourth. Recent research gives an even grimmer picture: as many municipalities provide supplementary benefits to minimum income recipients, obstacles on the way to employment can be significantly higher. A survey of 10 local situations by Anne and L'Horty (2002) indicated that moving from the minimum income to a full-time job on the minimum wage actually frequently implied an income $\operatorname{loss}^{14}$ !

From 1998 on, a new policy direction was taken and a series of measures were introduced to reduce the disincentive effects of effective marginal labour income taxation. In 1998, the possibility of cumulating the minimum income and a wage income for up to one year was offered to minimum income recipients. In 1999, the housing tax was reformed in order to

\footnotetext{
${ }^{13}$ Piketty (1998) has shown that the participation rate in the eligible population has dropped by 15 percentage points.

${ }^{14}$ Anne and L'Horty compute a «reservation working time » which for single persons stands at $26 \mathrm{~h}$ before taking into account local benefits but at $44 \mathrm{~h}$ after they are taken into account.
} 
limit the disincentive effects of existing exemptions. In 2000, housing allowances were reformed in the same direction. Finally, a tax credit on labour income, the Prime pour l'emploi, was introduced in 2001, together with a reform of the income tax exemption regime for low-income households. Of those measures, the most symbolic and therefore the most controversial one was the Prime pour l'emploi. Although a major union supported it, several others opposed vehemently to what they perceived as an intrusion of the state in the wage bargaining process and as a threat to the minimum wage. The measure was also controversial within the socialist-led parliamentary majority. But it was nevertheless legislated and is now part of the landscape.

According to Hagneré and Trannoy (2002), those reforms have had a very substantial effect on the incentive to take up a job ${ }^{15}$. First, they have eliminated many peaks in the effective marginal tax rate on labour income, making thereby disposable income a monotonic function of the primary income. Second, taking up a job, even part time, always increases disposable income in the first year: effective marginal tax rates on labour income are below $25 \%$ as recipients keep the minimum income for the entire year. For example, the gain from working full time is increased by $€ 3500$ in comparison to the pre-reform situation. Third, in the long run moving to a part-time job still involves a very modest gain, but the annual gain from working full time is increased by $€ 1500$. Fourth, other things being equal, effective marginal tax rates are always higher for part-time jobs than for full-time jobs. The tax and benefit system thus provides incentives to work full time: part-time work can only pay as a labour market entry strategy.

Although the improvement is significant, there are two noticeable downsides. The first one is the high budgetary costs of the reforms: around $€ 4.5 \mathrm{bn}$, close to a third of a percentage point of GDP (the cost was in fact higher before it was decided in 2002 not to implement the third planned increase in the Prime pour l'emploi). This would be a high price to pay if only efficiency gains had to be expected. The labour supply effects of the reforms have not been studied extensively yet, but they are generally expected to be modest, as the Prime pour l'emploi may have ambiguous effects on the participation of women (Cahuc, 2001, Laroque and Salanié, 2001). However the reforms, especially the Prime pour l'emploi which was introduced simultaneously with a cut in the marginal income tax rates, also had distributional objectives.

\footnotetext{
${ }^{15}$ Hagneré and Trannoy however do not take local benefits into account. They also assume full implementation of the Prime pour l'emploi, which was supposed to be phased in in three steps. However, the 2003 budget does not implement the third step as initially planned.
} 
The second downside is that the design of the reforms signals a disputable aversion for parttime work. It is frequently claimed that public policy should not 'subsidise' part-time work. However, as effective marginal tax rates on part-time labour income are significantly higher than on full-time income, this is far from being the case. Neutrality with respect to individual choices would imply having the same effective tax rate. The government has signalled an intention to go in this direction.

\section{Unemployment insurance}

Another focus of recent discussions and reforms has been the functioning of the labour market. French policy in this field has been noticeably prone to instability. Before 1992, unemployment benefits were typically constant for 14 months, then dropped to a level equivalent to that of the minimum income. The sudden drop was replaced in 1992 by a stepby-step decline: benefits were reduced by $17 \%$ every four months until they reached the minimum level. In 2001, employers and unions ${ }^{16}$ agreed on a new system which has two main characteristics. First, it puts a new focus on the balance between rights and responsibilities. Each recipient must sign a contract which spells out its obligations. No new legally binding obligations are introduced, but the contract signals a willingness to enforce the existing obligation of active job search ${ }^{17}$. The contract also spells out the responsibility of the employment services. Second, the step-by-step decline in the level of the benefits is eliminated. Benefits are now constant without duration limits, provided the recipient fulfils its obligations.

The effects of the 1992 reform have been studied by Dormont, Fougère and Prieto (2001). They find that the sudden benefit drop after 14 months was associated with a peak in the rate of exit from unemployment which was unsurprisingly eliminated by the reform. Their other finding is that the average exit rate has declined with the reform, especially for skilled persons. No research on the new reform has been published yet. Preliminary findings by point to a positive effect of signing the contract. However, anecdotal evidence suggests enforcement is frequently lacking, in part because of a scarcity of resources. The credibility of the system is thus uncertain. Furthermore, as deteriorating economic conditions have led to a deficit in the unemployment insurance system, its sustainability is also questionable.

\section{Employment protection}

\footnotetext{
${ }^{16}$ Not all unions agreed, but this was not necessary to make the agreement valid.

17 In the previous regime, benefits were conditional on active job seeking behaviour, but in practice the conditionality was low.
} 
French governments have in recent years consistently refrained from reducing employment protection for employees on permanent contracts (if anything, legislation introduced in 2002 increased the delays for companies undertaking collective layoffs). Liberalisation has basically taken place through the development of temporary contracts. As a consequence, France ranks high as regards the strictness Employment Protection Legislation (EPL) as measured by the OECD.

In this respect, governments essentially respond to popular demand. Public opposition to layoffs is widespread and vocal, especially in small towns, in manufacturing and among senior workers. It has not been weakened by the introduction of temporary contracts as employees perceive permanent contracts as a guarantee against the risk of unemployment. It has not receded in the years of high employment creation either.

The rationale for opposition to layoffs is that they generally imply remaining out of employment for a long period (50\% of employees are still without a job after 20 months) and entail a durable income loss (Margolis 2001, 2002). Furthermore, the probability of finding a new job is very low for workers above 50 .

Discussions on alternative security concepts based on employability, training and placement have started but have not yet resulted in reform proposals.

\section{Conclusions}

In the last decade, successive left-wing and right-wing French governments have introduced important changes in labour market policy. In spite of significant differences, a noticeable degree of continuity has prevailed in their approach. Common characteristics include:

- a refusal to consider radical reform in areas such as employment protection legislation, unemployment insurance, and minimum wage legislation ${ }^{18}$;

- a sympathy for active labour market policies;

- a strong focus on fostering labour demand, especially for unskilled workers;

- a heavy reliance on tax or social security incentives;

- a willingness to contemplate unconventional measures such as working time reduction.

The implicit diagnosis behind this approach was that the French labour markets suffered more from insufficient labour demand than from high firing costs, excessive unionisation or overly

\footnotetext{
${ }^{18}$ The creation of a minimum wage for young workers was attempted in the early $1990 \mathrm{~s}$, but the government had to backtrack in front of strong student opposition.
} 
generous welfare benefits. Judging from the job creation of the late 1990s and the early 2000s, this approach has produced better results than anticipated by policymakers (not to speak of the view of outside observers). While the level of employment remains modest in comparison to the achievements of some other European countries, this can be taken as an encouragement for unconventional active labour market policies.

There are however three important caveats.

First, direct evidence on the effect of French labour market policy remains scant. Some other European countries, which have not made similar choices, have also experienced favourable developments. Why labour productivity has slowed down simultaneously in several European countries remains a puzzle for research.

Second, the budgetary cost of this strategy is far from trivial. Table 7 gives some orders of magnitude. Although it does not include data after 2000 and does not take into account the cost of tax and benefits reforms, the size of the effort and the degree to which expenditures have been reoriented towards active policies is already noticeable. As developed in the text, expenditures on the financing of social security contribution cuts should increase from $0.8 \%$ of GDP in 2000 to $1.2 \%$ by the mid-2000s; the (gross) cost of the reforms in the tax-benefits system through the Prime pour l'emploi and related measures amounts to another 0.3 percentage points; finally, the cost of reforming the unemployment insurance system can be evaluated in the neighbourhood of $0.1 \%$ of GDP. The cost of supporting business sector employment through social security contribution cuts and tax incentives, which amounted to $1.2 \%$ of GDP in 2000 (Table 7) should thus reach some 2\% of GDP in 2005. 
Table 7: Public Spending on Employment Programmes, 1990-2000

\begin{tabular}{|l|rrr|}
\multicolumn{3}{c}{} & \multicolumn{2}{c|}{ In percent of GDP } \\
\hline & 1990 & 1997 & 2000 \\
Unemployment benefits & 1.32 & 1.55 & 1.46 \\
Subsidies to labour supply reductions & 0.56 & 0.36 & 0.27 \\
Support to non-business sector employment & 0.07 & 0.24 & 0.41 \\
Support to business sector employment & 0.22 & 1.13 & 1.23 \\
- of which social security contribution cuts & 0.00 & 0.58 & 0.82 \\
Training programmes for unemployed persons & 0.34 & 0.39 & 0.27 \\
Functioning of the labour market & 0.06 & 0.07 & 0.08 \\
\hline Total & 2.57 & 3.74 & 3.73 \\
\hline
\end{tabular}

Third, new priorities must be addressed if unemployment is to be further reduced. The experience of 2000-2001 suggests some issues that should rank high in the priority list: the functioning of the labour market and the efficiency of the employment agency in contributing to the labour demand-labour supply matching process; the retraining system, which is notoriously inefficient; the participation of older workers, which remains exceptionally low; mobility; and alternative approaches to workers security that do not rely on employment protection legislation. Adopting the same kind of strategy to address or at least alleviate these problems would require significant additional resources against the background of a deteriorating budgetary situation. In a context of increasing strains linked to the ageing of the population and intra-European tax competition, it is doubtful that those resources will be readily available, even if cyclical conditions improve.

In other words, France has been able to achieve noticeable results in the reduction of mass unemployment while preserving essential tenets of its social and labour relation models, but at a significant budgetary cost. Whether this strategy is financially and politically sustainable is likely to be increasingly an issue in the years to come.

\section{References}

Anne, Denis, et Yannick L'Horty (2002), « Transferts sociaux locaux et retour à l'emploi », Economie et Statistique $\mathrm{n}^{\circ} 357-358$, available on www.insee.fr.

Audric, Sophie (2001), « La reprise de la croissance de l'emploi profite-t-elle aussi aux nondiplômés? », Document de travail G2001-02, INSEE, available on www.insee.fr. .

Barrat, Olivier, et Catherine Daniel (2002), « La négociation d'entreprise de 1995 à 2000 », Données sociales, INSEE. 
D'Autume, Antoine, et Pierre Cahuc (1997) «Réduction de la durée du travail et emploi : une synthèse », in Pierre Cahuc and Pierre Granier (eds.), La réduction du temps de travail : une solution pour l'emploi?, Economica.

Blanchard, Olivier, and Jean-Paul Fitoussi (1998), Croissance et chômage, Conseil d'analyse économique, Report n ${ }^{\circ} 4$, La Documentation française, Paris.

Blanchard, Olivier, and Augustin Landier (2002), "The Perverse Effect of Partial Labour Market Reform: Fixed-Term Contracts in France", The Economic Journal 112, June.

Blanchard, Olivier, and Justin Wolfers (2000), "The Role of Shocks and Institutions in European Unemployment: The Aggregate Evidence”, Economic Journal 110, March.

Bloch-London, Catherine, Trong-Hien Pham et Serge Zilberman (2002), « La mise en oeuvre des 35 heures », Données sociales, INSEE.

Bourguignon, François, et Dominique Bureau (1999), L'architecture des prélèvements en France: état des lieux et voies de réforme, Rapport du Conseil d'analyse économique ${ }^{\circ} 17$, available on www.cae.gouv.fr.

Cahuc, Pierre (2001), «L'expérience française de réduction du temps de travail : moins d'emplois et plus d'inégalités », Revue française d'économie volume XV n³, January.

Cahuc, Pierre (2002), « Baisser les charges sociales : jusqu'où et comment ?», Document de travail, Centre d'observation économique de la Chambre de commerce de Paris, juillet.

Campens, Etienne, Sébastien Doisy, Sandrine Duchêne et Christian Gianella (2001), « Allégements de charges au voisinage du SMIC et chômage structurel : une modélisation à partir d'un mdoèle de matching avec hétérogénéité des qualifications », miméo.

Carnot, Nicolas, and Alain Quinet (2000), « L'enrichissement du contenu en emploi de la croissance : une tentative de clarification », in Pisani-Ferry (2000).

Conseil de l'Emploi, des Revenus et de la Cohésion sociale (CERC) (2001), Accès à l'emploi et cohésion sociale, rapport numéro 1, La Documentation française, available on www.cerc.fr.

Conseil d'Orientation des Retraites (COR) (2002), Retraites : renouveler le débat entre les générations, Premier rapport 2001, La Documentation française.

Cette, Gilbert (2000), « Les 35 heures : quels effets et quels risques ? », in Pisani-Ferry (2000).

Cette, Gilbert, et Dominique Taddei (1998), La réduction de la durée du travail, Le Livre de Poche.

Cette, Gilbert, Jacques Mairesse, and Yusuf Kocoglu (2002), "Diffusion of ICT and Growth of the French Economy over the Long Term, 1980-2000”, International Productivity Monitor n ${ }^{\circ} 4$, Spring.

Charpin, Jean-Michel (1993), L'économie française en perpective, La Découverte/Commissariat du Plan.

Crépon, Bruno, et Rosen Desplatz (2001), « Une nouvelle évaluation des effets des allégements de charges sur les bas salaires », Economie et statistique $\mathrm{n}^{\circ}$ 348, available on www.insee.fr.

Crépon, Bruno, et Rosen Desplatz (2002), Reply to Sterdyniak (2002), Revue de l'OFCE n82, July.

Dormont, Brigite, Denis Fougère et Ana Prieto (2001), « L'effet de l'allocation unique dégressive sur la reprise d'emploi », Economie et statistique, $n^{\circ} 343$, available on www.insee.fr.

Gonzalez-Demichel, Christine, Emmanuelle Nauze-Fichet et Sébastien Seguin (2002), « Les performances du marché du travail au tournant du $\mathrm{XXI}^{\circ}$ siècle », Données sociales, INSEE, novembre.

Gurgand, Marc, et David Margolis (2001), « RMI et revenus du travail : une évaluation des gains financiers à l'emploi », Economie et statistique n ${ }^{\circ}$ 308/309/310, available on www.insee.fr. 
Hagneré, Cyrille, et Alain Trannoy (2001), «L'impact conjugué de trois ans de réforme sur les comportements d'activité, Economie et statistique, $n^{\circ} 346$, available on www.insee.fr.

Heyer, Eric, et Xavier Timbeau (2000), « 35 heures : réduction réduite », Revue de l’OFCE n74, juillet.

INSEE (2002), L'économie française 2002-2003, Le Livre de Poche.

Jugnot, Stéphane (2002), “Combien d'emploi créés par la réduction du temps de travail ?, Données sociales, INSEE.

Katz, Lawrence, and Alan Krueger (1999), "The High-Pressure US Labor Market of the 1990s", Brookings Papers on Economic Activity ${ }^{\circ} 1$.

Laroque, Guy, et Bernard Salanié (2000), « Une décomposition du non-emploi en France », Economie et statistique $\mathrm{n}^{\circ} 331$, available on www.insee.fr.

L'Horty, Yannick (2001), comment on Crépon et Desplatz (2001).

Marchand, Olivier, et Claude Thélot (1997), Le Travail en France, 1800-2000, Nathan.

Margolis, David (2000), «Workers Displacement in France », Document de travail CREST-INSEE ${ }^{\circ}$ 2000-01, available on www.crest.fr.

Margolis, David (2002), « Licenciements collectifs et délais de reprise d'emploi », Economie et Statisique $\mathrm{n}^{\circ} 351$, available on www.insee.fr.

Melka, Johanna, Laurence Nayman, Soledad Zignago and Nanno Mulder (2003), « Skills, Technology and Growth : is ICT the Key to Success », CEPII Working Paper $\mathrm{n}^{\circ}$ 2003-04, May, available on www.cepii.fr.

Ministry of Finance (1997), "Tendances de long terme de l'économie française", in DARES/DP/INSEE, Bilan économique et social de la France, La Documentation française.

Ministry of Finance (2002), Rapport économique, social et financier to the parliament.

Nauze-Fichet, Emmanuelle, et Magda Tomasini (2002), « Diplôme et insertion sur le marché du travail : approches socioprofessionnelle et salariale du déclassement », Economie et Statistique $\mathrm{n}^{\circ} 354$.

OECD (2000), Economic Survey of France.

Piketty, Thomas (1998), «L'impact des incitations financières au travail sur les comportements individuels : une estimation sur le cas français », Economie et prévision $n^{\circ} 132-133$.

Pisani-Ferry, Jean (2000), Les chemins du plein emploi, rapport du Conseil d'analyse économique $\mathrm{n}^{\circ} 30$, La Documentation française, available on www.cae.gouv.fr.

Rouilleault, Henri (2001), Réduction du temps de travail : les enseignements de l'observation, Commissariat du Plan, July.

Sterdyniak, Henri (2002), «Fiche de lecture » on Crépon and Desplatz (2002), Revue de l'OFCE n81, April.

Taddei, Dominique (1997), La réduction du temps de travail, rapport du Conseil d'analyse économique ${ }^{\circ} 1$, La Documentation française. 


\section{CESifo Working Paper Series}

(for full list see www.cesifo.de)

1013 Seppo Kari and Jouko Ylä-Liedenpohja, Taxation and Valuation of International Real Investments, August 2003

1014 James Heckman, Rosa Matzkin and Lars Nesheim, Simulation and Estimation of Hedonic Models, August 2003

1015 Biswa N. Bhattacharyay, Towards a Macro-Prudential Leading Indicators Framework for Monitoring Financial Vulnerability, August 2003

1016 J. Stephen Ferris and Stanley L. Winer, Searching for Keynes: With Application to Canada, 1870-2000, August 2003

1017 Massimo Bordignon, Luca Colombo and Umberto Galmarini, Fiscal Federalism and Endogenous Lobbies' Formation, August 2003

1018 Annette Alstadsæter, The Dual Income Tax and Firms' Income Shifting through the Choice of Organizational Form and Real Capital Investments, August 2003

1019 Peter Fredriksson and Bertil Holmlund, Optimal Unemployment Insurance Design: Time Limits, Monitoring, or Workfare?, August 2003

1020 Kashif S. Mansori, Following in their Footsteps: Comparing Interest Parity Conditions in Central European Economies to the Euro Countries, August 2003

1021 Christoph Borgmann and Matthias Heidler, Demographics and Volatile Social Security Wealth: Political Risks of Benefit Rule Changes in Germany, August 2003

1022 Kjell Erik Lommerud, Bjørn Sandvik and Odd Rune Staume, Good Jobs, Bad Jobs and Redistribution, August 2003

1023 Patrick Karl O'Brien, The Governance of Globalization: The Political Economy of Anglo-American Hegemony, 1793-2003, September 2003

1024 Antonio Ciccone and Giovanni Peri, Skills' Substitutability and Technological Progress: U.S. States 1950-1990, September 2003

1025 Bjørn Sandvik, Optimal Taxation and Normalisations, September 2003

1026 Massimo Bordignon and Gilberto Turati, Bailing Out Expectations and Health Expenditure in Italy, September 2003

1027 José A. Herce, Namkee Ahn, Ricard Génova, and Joaquín Pereira, Bio-Demographic and Health Aspects of Ageing in the EU, September 2003 
1028 John Komlos and Marieluise Baur, From the Tallest to (One of) the Fattest: The Enigmatic Fate of the American Population in the $20^{\text {th }}$ Century, September 2003

1029 Stefan Napel and Mika Widgrén, Bargaining and Distribution of Power in the EU's Conciliation Committee, September 2003

1030 Kai Li and Dale J. Poirier, Relationship Between Maternal Behavior During Pregnancy, Birth Outcome, and Early Childhood Development: An Exploratory Study, September 2003

1031 Ivar Ekeland, James J. Heckman, and Lars Nesheim, Identifcation and Estimation of Hedonic Models, September 2003

1032 Kjetil Bjorvatn and Alexander W. Cappelen, Decentralization and the Fate of Minorities, September 2003

1033 Lars-Erik Borge and Jørn Rattsø, The Relationships Between Costs and User Charges: The Case of a Norwegian Utility Service, September 2003

1034 Maureen Were and Nancy N. Nafula, An Assessment of the Impact of HIV/AIDS on Economic Growth: The Case of Kenya, September 2003

1035 A. Lans Bovenberg, Tax Policy and Labor Market Performance, September 2003

1036 Peter Birch Sørensen, Neutral Taxation of Shareholder Income: A Norwegian Tax Reform Proposal, September 2003

1037 Roberta Dessi and Sheilagh Ogilvie, Social Capital and Collusion: The Case of Merchant Guilds, September 2003

1038 Alessandra Casarico and Carlo Devillanova, Capital-skill Complementarity and the Redistributive Effects of Social Security Reform, September 2003

1039 Assaf Razin and Efraim Sadka, Privatizing Social Security Under Balanced-Budget Constraints: A Political-Economy Approach, September 2003

1040 Michele Moretto, Paolo M. Panteghini, and Carlo Scarpa, Investment Size and Firm's Value under Profit Sharing Regulation, September 2003

1041 A. Lans Bovenberg and Peter Birch Sørensen, Improving the Equity-Efficiency Tradeoff: Mandatory Savings Accounts for Social Insurance, September 2003

1042 Bas van Aarle, Harry Garretsen, and Florence Huart, Transatlantic Monetary and Fiscal Policy Interaction, September 2003

1043 Jerome L. Stein, Stochastic Optimal Control Modeling of Debt Crises, September 2003

1044 Thomas Stratmann, Tainted Money? Contribution Limits and the Effectiveness of Campaign Spending, September 2003 
1045 Marianna Grimaldi and Paul De Grauwe, Bubbling and Crashing Exchange Rates, September 2003

1046 Assar Lindbeck and Dennis J. Snower, The Firm as a Pool of Factor Complementarities, September 2003

1047 Volker Grossmann, Firm Size and Diversification: Asymmetric Multiproduct Firms under Cournot Competition, September 2003

1048 Dan Anderberg, Insiders, Outsiders, and the Underground Economy, October 2003

1049 Jose Apesteguia, Steffen Huck and Jörg Oechssler, Imitation - Theory and Experimental Evidence, October 2003

1050 G. Abío, G. Mahieu and C. Patxot, On the Optimality of PAYG Pension Systems in an Endogenous Fertility Setting, October 2003

1051 Carlos Fonseca Marinheiro, Output Smoothing in EMU and OECD: Can We Forego Government Contribution? A Risk Sharing Approach, October 2003

1052 Olivier Bargain and Nicolas Moreau, Is the Collective Model of Labor Supply Useful for Tax Policy Analysis? A Simulation Exercise, October 2003

1053 Michael Artis, Is there a European Business Cycle?, October 2003

1054 Martin R. West and Ludger Wößmann, Which School Systems Sort Weaker Students into Smaller Classes? International Evidence, October 2003

1055 Annette Alstadsaeter, Income Tax, Consumption Value of Education, and the Choice of Educational Type, October 2003

1056 Ansgar Belke and Ralph Setzer, Exchange Rate Volatility and Employment Growth: Empirical Evidence from the CEE Economies, October 2003

1057 Carsten Hefeker, Structural Reforms and the Enlargement of Monetary Union, October 2003

1058 Henning Bohn and Charles Stuart, Voting and Nonlinear Taxes in a Stylized Representative Democracy, October 2003

1059 Philippe Choné, David le Blanc and Isabelle Robert-Bobée, Female Labor Supply and Child Care in France, October 2003

1060 V. Anton Muscatelli, Patrizio Tirelli and Carmine Trecroci, Fiscal and Monetary Policy Interactions: Empirical Evidence and Optimal Policy Using a Structural New Keynesian Model, October 2003

1061 Helmuth Cremer and Pierre Pestieau, Wealth Transfer Taxation: A Survey, October 2003 
1062 Henning Bohn, Will Social Security and Medicare Remain Viable as the U.S. Population is Aging? An Update, October 2003

1063 James M. Malcomson, Health Service Gatekeepers, October 2003

1064 Jakob von Weizsäcker, The Hayek Pension: An efficient minimum pension to complement the welfare state, October 2003

1065 Joerg Baten, Creating Firms for a New Century: Determinants of Firm Creation around 1900 , October 2003

1066 Christian Keuschnigg, Public Policy and Venture Capital Backed Innovation, October 2003

1067 Thomas von Ungern-Sternberg, State Intervention on the Market for Natural Damage Insurance in Europe, October 2003

1068 Mark V. Pauly, Time, Risk, Precommitment, and Adverse Selection in Competitive Insurance Markets, October 2003

1069 Wolfgang Ochel, Decentralising Wage Bargaining in Germany - A Way to Increase Employment?, November 2003

1070 Jay Pil Choi, Patent Pools and Cross-Licensing in the Shadow of Patent Litigation, November 2003

1071 Martin Peitz and Patrick Waelbroeck, Piracy of Digital Products: A Critical Review of the Economics Literature, November 2003

1072 George Economides, Jim Malley, Apostolis Philippopoulos, and Ulrich Woitek, Electoral Uncertainty, Fiscal Policies \& Growth: Theory and Evidence from Germany, the UK and the US, November 2003

1073 Robert S. Chirinko and Julie Ann Elston, Finance, Control, and Profitability: The Influence of German Banks, November 2003

1074 Wolfgang Eggert and Martin Kolmar, The Taxation of Financial Capital under Asymmetric Information and the Tax-Competition Paradox, November 2003

1075 Amihai Glazer, Vesa Kanniainen, and Panu Poutvaara, Income Taxes, Property Values, and Migration, November 2003

1076 Jonas Agell, Why are Small Firms Different? Managers’ Views, November 2003

1077 Rafael Lalive, Social Interactions in Unemployment, November 2003

1078 Jean Pisani-Ferry, The Surprising French Employment Performance: What Lessons?, November 2003 